\title{
Imprint stability and plasticity during development
}

\author{
Sarah-Jayne Mackin, Avinash Thakur*, and Colum P Walsh \\ Genomic Medicine Research Group, School of Biomedical Sciences, Ulster University, Northern Ireland, UK
}

Correspondence should be addressed to C PWalsh; Email: cp.walsh@ulster.ac.uk

*(A Thakur is currently at Terry Fox Laboratory, BC Cancer Research Centre, 675 West 10th Avenue, Room 13-112, Vancouver, BC V5Z 1L3, Canada)

\begin{abstract}
There have been a number of recent insights in the area of genomic imprinting, the phenomenon whereby one of two autosomal alleles is selected for expression based on the parent of origin. This is due in part to a proliferation of new techniques for interrogating the genome that are leading researchers working on organisms other than mouse and human, where imprinting has been most studied, to become interested in looking for potential imprinting effects. Here, we recap what is known about the importance of imprints for growth and body size, as well as the main types of locus control. Interestingly, work from a number of labs has now shown that maintenance of the imprint post implantation appears to be a more crucial step than previously appreciated. We ask whether imprints can be reprogrammed somatically, how many loci there are and how conserved imprinted regions are in other species. Finally, we survey some of the methods available for examining DNA methylation genome-wide and look to the future of this burgeoning field.

Reproduction (2018) 156 R43-R55
\end{abstract}

\section{Introduction}

Genomic imprinting is a classic epigenetic phenomenon, and after X-inactivation, one of the best understood. In its simplest form, imprinting refers to genes showing monoallelic expression depending on their parent of origin (Bartolomei \& Ferguson-Smith 2011, Barlow \& Bartolomei 2014). There is however considerable variation seen in where in the body and when the imprinted expression is seen. Imprints need to be set up when the alleles are separated during germ line development and then the imprints need to be interpreted by the transcriptional machinery in the target tissues. Recent work has advanced our understanding of (1) the processes behind establishment of imprints as well as (2) how the imprinting mark is maintained and interpreted. For the former, there is an excellent review by Kelsey (Hanna \& Kelsey 2014). Here, we wish to focus on the latter process of maintenance, as well as ask what we have learned from species other than mouse, and touch on the technical difficulties, which arise when working in organisms other than mouse and human, where the most resources are available.

\section{Importance of known imprints for body mass and feeding}

\section{Effects on growth and body size}

One of the most enduring explanations for why imprinting may have arisen is the parental conflict hypothesis (Haig \& Graham 1991, Moore \& Haig 1991). Many imprinting phenomena involve effects on growth, nutrition or metabolic balance, and this theory was partly based on observations from uniparental conceptuses where the paternal contribution seemed particularly important for the embryo, while the maternal genome was important for placental development (Barton et al. 1984). This turned out to be partly due to the paternal expression of the major growth factor insulin-like growth factor-2 (IGF2), and the maternal expression of an antagonistic binding partner insulin-like growth factor-2 receptor (IGF2R), one of the first observations leading to the idea of parental conflict in imprinting. Several imprinted genes were also shown to be dysregulated in the placentas of these mouse conceptuses (Walsh et al. 1994), including genes specifically imprinted only in placenta such as Mash2 (Guillemot et al. 1995). Indeed, the placenta is generally considered to have a higher number of imprinted genes than in other tissues (Court et al. 2014); though in the mouse and human, many of these are maternally expressed. An alternative to the parental conflict hypothesis, called coadaptation theory, also stresses the importance of interactions between offspring and parents for nutrient provision and acquisition (Keverne \& Curley 2008).

Much of the support for these theories has been gleaned in mouse systems. Interestingly however, a single nucleotide substitution in a non-coding region of IGF2 underlies a major QTL in pigs that affects muscle growth, heart size and fat deposition (Jeon et al. 1999,

\footnotetext{
https://doi.org/10.1530/REP-18-0051
} Online version via www.reproduction-online.org 
Van Laere et al. 2003). The mutation disrupts the binding of a recently evolved nuclear protein ZBED6 that appears to be acting as a repressor of IGF2 transcription, not only in pigs but potentially in all placental mammals, where it is highly conserved (Markljung et al. 2009, Younis et al. 2018). A more general defect called large offspring syndrome (LOS) in livestock (namely sheep and cattle) also involves perturbed imprinted gene expression, thought to be due to preimplantation disturbances. LOS is associated with an increase in gestational length, $50-80 \%$ increase in birth weight, hypoglycaemia and an enlarged tongue (Chen et al. 2013). The phenotypic characteristics of LOS are reminiscent of those exhibited by Beckwith-Wiedemann syndrome in humans, which can be driven by defects at the IGF2 imprint control region (ICR) or the nearby $K v D M R$ (Weksberg et al. 2010). Rivera and colleagues found however that LOS was not characterised by loss of imprinting at any one locus, but seemed instead to be accompanied by misregulation of multiple imprinted genes, with greater dysregulation seen in the largest offspring (Chen et al. 2015). The requirement for delivery of large offspring by caesarean section, the frequent post-natal mortality, and other complications, mean that LOS restricts the full use of modern reproductive strategies in ruminants.

The callipyge muscle hypertrophy phenotype observed in sheep is also caused by a SNP, in this case located intergenically between known imprinted genes, the paternally expressed DLK1 and maternally expressed MEG3 long non-coding RNA (IncRNA) within the telomeric region of chromosome 18 . This region is known to share a high degree of homology with other mammals including cattle and humans (Freking et al. 2002a,b). Callipyge syndrome can cause adverse changes to normal muscle development, body shape and even changes to meat quality (Freking et al. 2002a) and the composition of their carcass (Bidwell et al. 2014). Interestingly, the expression of this unique phenotype is the only distinctive example of polar overdominance in mammals (Freking et al. 2002a). Heterozygous callipyge sheep have a normal maternal allele while carrying the callipyge SNP on the paternal allele (Bidwell et al. 2014).

\section{Neurological effects involving feeding and weight gain}

Another general feature of imprinted genes is that many are transcribed primarily in the neurons and in some cases only show imprinted expression there. While initially this posed difficulties for the parental conflict hypothesis, which was originally proposed on the basis of imprinting affecting placentation and embryonic growth, with the discovery that some of the genes controlled feeding behaviour or weight gain later in life, these results could be reconciled with the hypothesis. Thus, Prader-Willi syndrome in humans (OMIM176270), where transcription of the neuronal genes at the SNRPN cluster are affected, involves excessive eating (hyperphagia), while the Peg3 gene in mouse is crucial for feeding behaviour (Curley et al. 2005). Likewise, loss of expression of the Gnas and Gnasxl genes in mice can give hypo- and hyperphagia respectively, while a number of other imprinted genes also have effects on fat/body mass ratios (Peters 2014).

Furthermore, the aforementioned LOS or large calf syndrome can often cause a reluctance to suckle in young cattle. This may be due to the dysregulation of a number of imprinted genes reported in these animals (Zhang et al. 2004, Chen et al. 2015). However apart from these few studies, little work appears to have been done to date investigating imprinted genes and feeding behaviours outside of the mouse and human systems.

\section{Imprinting disorders in hybrid species: the case of the hinny}

A classic example of parent-of-origin effects in livestock is the horse-donkey cross: when the horse is the sire, the resultant offspring is a mule; if the donkey is the sire, then a hinny results, and these are quite distinguishable animals even though their genomic complements are the same. Initially, it was argued that this may be due to differences in uterine environment and the placentaluterine exchange. Early investigation identified that serum concentrations of the placental hormone equine chorionic gonadotrophin were considerably higher in mule than in hinny pregnancies, suggestive of paternal genome-specific expression (Allen 1969). Recent use of RNA sequencing of trophoblast tissue from embryos derived from each reciprocal cross of horse and donkey (Wang et al. 2013) identified 15 'core' imprinted genes that are conserved in equids, mouse and human, including genes such as SNRPN, H19 and PEC3. Interestingly, paternal expression seems favoured, as $10 / 15$ core imprints - and all of the larger group of 78 genes identified in that study - showed paternal bias, but with many only imprinted in placenta. Additionally, some of the genes in the second, larger group showed incomplete or variable silencing. The authors speculate that this variability may reflect the flexibility of the structure and function of the placenta, which varies widely between mammals. Interestingly, XIST does not seem to be one of the imprinted genes, and $\mathrm{X}$-inactivation in the placenta is random in both the horse parent and the hybrids (Wang et al. 2012).

\section{Establishment of parental-specific methylation at imprints}

It was recognised already from early studies that imprints would most likely be established in the germ line, where each allele of the diploid pair is separate and therefore can be separately marked. While studies on germ cell development were long hampered by the 
difficulty of access to the early stages of development of this migratory cell population, and the small numbers of cells involved, recent advances in cell labelling and separation, coupled with the refinement of sequencing techniques and single-cell approaches (see below) have meant that we now have a much deeper understanding of the process of imprint establishment. This area has been dealt with very expertly by others in a recent review (Hanna \& Kelsey 2014). We will concentrate here on insights gained in some studies published since then, confining ourselves first to a brief recap of the varied imprinting mechanisms.

\section{The main types of imprinted loci and their structures}

Current studies suggest that there are three main types of imprinted locus, controlled by different mechanisms. This has implications for where the imprint controllers are located and what they look like, as well as how the locus might respond to different perturbations.

\section{Insulator}

The archetype here is the cluster of genes around the H19 locus (Bartolomei \& Ferguson-Smith 2011): these are controlled by an intergenically located ICR that is not a CpG island (CGI) (Bird 1987) but is relatively CG rich, making it sensitive to DNA methylation. The ICR contains several repeats of a sequence that binds the insulator protein CTCF. Methylation blocks CTCF binding on the paternal allele at the locus (Bell \& Felsenfeld 2000, Hark et al. 2000), preventing H19 transcription but facilitating expression of $\operatorname{lgf} 2$ and, in mouse, the Insulin 2 gene expressed in the yolk sac. The mark on the ICR that is set up in the germ cells is called a primary differentially methylated region ( $\left.1^{\circ} \mathrm{DMR}\right)$ or gametic DMR (gDMR). Methylation that occurs post implantation, for example, on the H19 promoter after it has already been silenced, is known as a secondary $\left(2^{\circ}\right)$ DMR or somatic DMR (sDMR). There are a number of other imprinted loci with CTCF-binding sites, in some cases lacking CGl, where this protein is thought to play an important role (Prickett et al. 2013).

\section{Long non-coding RNA promoter}

Here the index locus is $\lg 2 \mathrm{r}$ that, unlike $H 19$, is an orphan imprinted gene. The DMR at the lgf $2 r$ promoter was, against expectation, the secondary DMR, and the primary DMR and functional ICR were found to be located at an intragenic island. This turned out to control transcription of an antisense IncRNA, whose transcription blocked the sense transcript in cis (Sleutels et al. 2002). This type of arrangement is also seen at the Kcnq1, Grb10 and DIk1 loci among others (Barlow \& Bartolomei 2014) and as more IncRNA are uncovered, this is becoming the largest group.

\section{Promoter}

For some imprinted loci such as Snrpn, Plag/1 and Grb10, transcription appears to be directly regulated by methylation of the promoter. Here, a promoter CGI is methylated to block transcription rather than any indirect mechanism. Although there is no antisense transcript, the Snrpn promoter does drive the production of a long RNA called Snurf/Snrpn that extends far downstream and contains multiple small RNA species that are processed from it (Buiting 2010), so it could be argued that it falls into the IncRNA category. However, for other genes in this group such as Grb10, no associated IncRNA have so far been found.

\section{Recent insights into imprint establishment}

Seminal work from the Bestor lab (Ooi et al. 2007) showed that the methyltransferase cofactor DNMT3L, which is only required in germline, bound to CGI but was blocked by methylation of the fourth lysine on the histone 3 tail (H3K4me3), and further that imprinting was disrupted in the knockout $(\mathrm{KO})$ mice. This link seemed strengthened by the finding that $\mathrm{KDM} 1 \mathrm{~B}$, a histone demethylase, was required to establish DNA methylation at imprints (Ciccone et al. 2009). However, the idea that DNMT3L might be specific to imprints was weakened by studies charting the establishment of methylation in oocytes, which showed that not only did many thousands of non-imprinted CGI became hypermethylated during oocyte maturation in a DNMT3L-dependent fashion, but DNMT3L was also required for methylation of many other non-CGI sequences (Kato et al. 2007, Smallwood et al. 2011, Kobayashi et al. 2012), suggesting that DNMT3L was in fact more of a general cofactor for the de novo methyltransferases, required primarily in the germline. What appeared instead to distinguish imprinted loci from other genes was that they could maintain their DMR in the face of the two main waves of remodelling in the early embryo, namely active and passive demethylation in the first few cell divisions and then the widespread de novo methylation seen post implantation. While few imprints are established in the male germ line, indications are that here too it is the maintenance of these DMR in the face of remodelling that separates them from other loci (Wang et al. 2014).

In effect, this marks a real shift in thinking with regards to imprinting, moving the emphasis away from the mechanisms that might target regions to become imprinted and towards identifying factors that are responsible for maintaining methylation differences at specific loci in the face of extensive epigenomic remodelling. Since this is a crucial new insight, we wish to expand on these findings below and begin by looking in more detail at the protein factors that may be involved prior to implantation, and then look at events post implantation. 


\section{Maintenance of imprints pre implantation}

Methylation marks are applied in a sex-specific manner during gametogenesis at the gDMRs and several proteins play important roles at various stages in this process. In particular, PgC7 (also referred to as Stella) is a critical component required in early maternal development and encodes a protein that has a SAP-like domain and a splicing factor-like domain (Aravind \& Koonin 2000). It has an important role in protecting the methylation status of imprinted genes by limiting demethylation in early embryogenesis (Nakamura et al. 2007) and as such is crucial for normal development. PGC7 has been experimentally shown to be actively expressed in primordial germ cells (PGCs) in mouse from E7.25 to E15.5 (Sato et al. 2002) but more importantly in the immature ovaries of the neonate females (Payer et al. 2003). Through depletion of the protein in the oocytes, Payer et al. (2003) found there was a reduction in the number of blastocysts, successful implantations and a reduction in the number of viable offspring. Nakamura et al. (2007) initially showed that PGC7 was required to maintain methylation on most imprinted loci in the preimplantation embryo, and later went on to show that PGC7 bound to $\mathrm{H} 3 \mathrm{~K} 9 \mathrm{me} 2$ at both paternally and maternally marked loci protects against active demethylation by TET3, a finding confirmed by others (Nakamura et al. 2012, Szabó \& Pfeifer 2012).

Another factor necessary for DNA methylation maintenance at ICRs in both mouse and human is ZFP57 (Kruppel-like zinc finger protein). Removal of the protein from the mouse zygote by use of both maternal and zygotic deletions caused embryonic death mid-gestation with a loss of all maternally methylated imprints (Li et al. 2008). In humans too, mutations in ZFP57 causes hypomethylation at multiple imprinted loci (Mackay et al. 2008). ZFP57 binds to a target hexanucleotide found at imprinted gDMRs, but only when methylated, and recruits DNMT1 and its cofactor UHRF1 to maintain methylation on the marked alleles (Quenneville et al. 2011). Additionally, through KAP1, it recruits SETDB1 that modifies the chromatin by adding H3K9me3. Indeed, loss of KAP1 also causes a failure to maintain imprints in the preimplantation embryo (Messerschmidt et al. 2012). Following this protective step in early development, DNA methylation is thought to be maintained along with this chromatin mark throughout the offspring's life at the respective ICRs (Proudhon et al. 2012).

\section{Post-implantation changes at transient and stable imprints}

The small number of known imprinted loci characteristically show (1) methylation differences between gametes (gDMRs), (2) dependence on
DNMT3L (Kato et al. 2007) and (3) an ability to maintain differential methylation during preimplantation development (Hanna \& Kelsey 2014). However, the genome-wide studies of the methylation landscape in germ cells mentioned earlier found that a relatively large number of loci (>1000) were methylated in a DNMT3Ldependent fashion in oocytes, but not sperm, and that many of them maintained high levels of methylation on the maternal allele until at least the blastocyst stage (Borgel et al. 2010, Smallwood et al. 2011, Shirane et al. 2013). Initial work by Michael Weber and colleagues (Borgel et al. 2010), suggested that not only imprinted loci, but also genes that were specifically expressed in the germline showed these features. Work from our own lab confirmed this (Rutledge et al. 2014) and further uncovered a class of genes expressed in brain showing these characteristics, suggesting three classes of genes with DNMT3L-programmed gDMRs: imprinted, germline and brain-specific genes (Fig. 1A). However, in stark contrast to the canonical imprinted loci, most of the brain and germline genes examined lost their differential methylation in adult tissues tested due to gains in methylation on the paternal, unmethylated allele. However, it was possible that among these latter two classes there were some true imprinted genes, which would show allele-specific expression in a tissueor stage-specific fashion.

To identify such genes, Ferguson-Smith and colleagues used ZFP57 binding as an extra criterion in addition to the three indicated above (Strogantsev et al. 2015). Using this approach, they could confirm recently identified imprints such as Cdh15 and Gpr1, and also uncovered evidence for imprinting at the Fkbp6 gene. Fkbp6 showed methylation in oocytes but not sperm in their study (Strogantsev et al. 2015), and maternal methylation was maintained in placenta at e16.5. In keeping with this, there was also predominant expression from the paternal allele as assayed using a transcribed SNP in interspecific mouse crosses, and this allele also carried H3K4me3 marks. Notably, in brain, both transcription and H3K4me3 continued to be associated with the paternal allele, even though the DNA methylation was assayed at $80 \%$, rather than the expected $50 \%$. This suggests that (1) either a subset of cells in brain continues to maintain the DNA methylation difference (in keeping with the low levels of transcription in this tissue); (2) some of the methylation being assayed may in fact be 5-hydroxymethylation (5hmC-see below), which is more prominent in brain and may cloud the picture, or most intriguingly (3) the DNA methylation difference is not as important as the histone marks. In addition to this complexity, Fkbp6 may show differences in imprinting due to genetic variation, since sperm methylation varies between mouse strains (Rutledge et al. 2014), and there have been reports of polymorphic imprinting in humans (Hanna et al. 2016). ZFP57 is also capable of mediating such strain-specific effects (Strogantsev et al. 2015). 


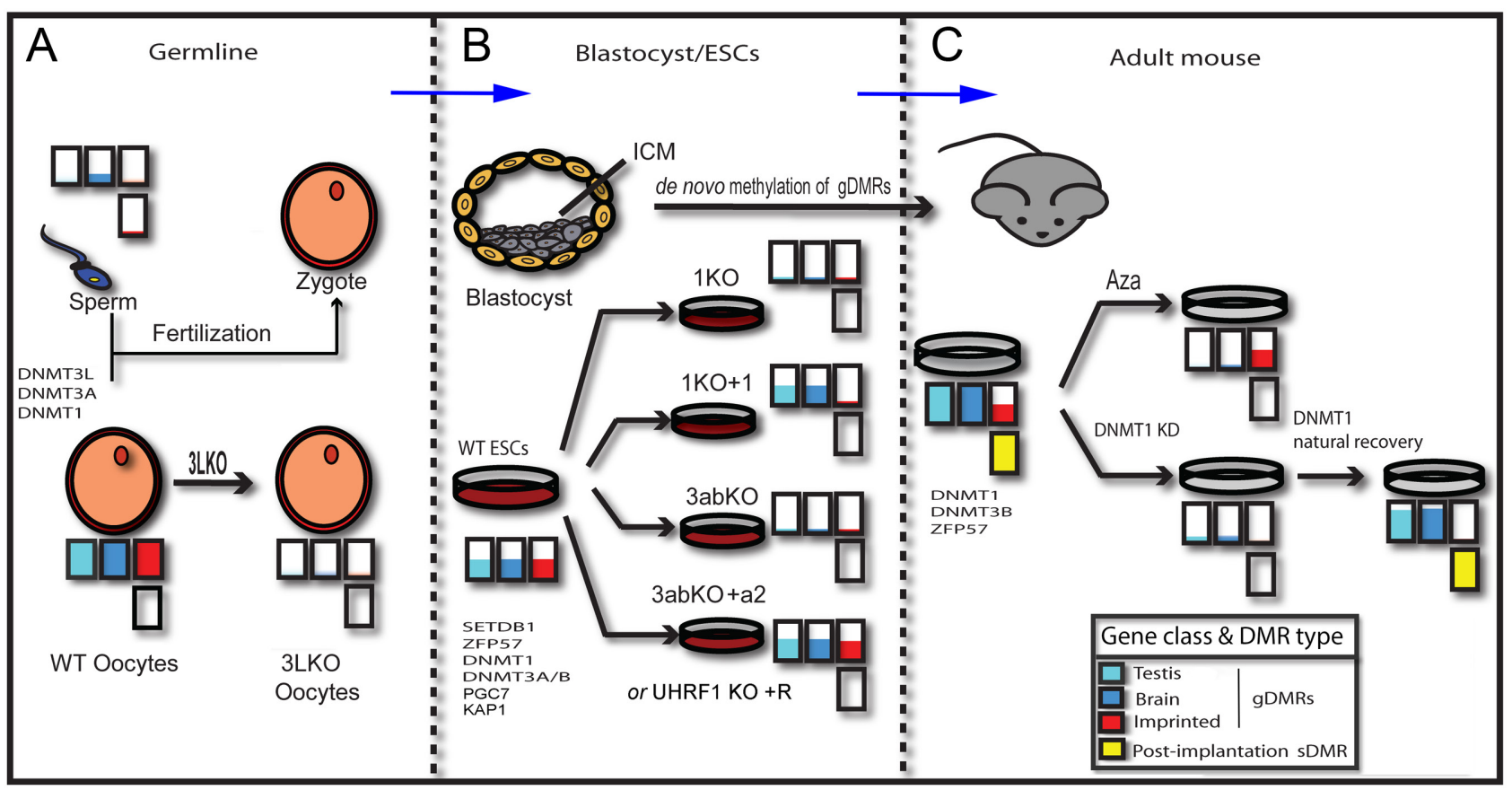

Figure 1 Some experimentally observed dependencies for imprint and imprint-like genes in mouse. Three classes of genes have gametic Differentially Methylated Regions (gDMR): testis, brain and imprinted genes (see key at bottom right: filled bar, 100\% methylation). Genes that acquire methylation post implantation (somatic or sDMR) are also represented. (A) Germline: All three classes of gDMRs lose methylation in oocytes lacking DNMT3L. (B) Blastocyst/ESC: The gDMRs retain their methylation aided by DNMT1 and by DNMT3A/B, with other possible contributors indicated. Loss of methylation on imprints in Dnmt1 knockout (1KO) cells cannot be rescued with Dnmt1 cDNA (1 Ko+1). In contrast, imprints in Dnmt3a/b KO (3abKO) can recover following rescue with Dnmt3a2 (3abKO+a2). (C) Adult: Unlike true imprints, the testis and brain gDMRs cannot maintain the unmethylated allele in the face of the wave of de novo methylation after implantation. Likewise, they are more sensitive to inhibitors such as 5'-aza-2'deoxycytidine (Aza).

Using one of the other three criteria above, namely dependence on DNMT3L, the Bourc'his lab also identified novel imprinted gDMRs including Cdh15, AK008011, Zfp777 and Zfp787 (Proudhon et al. 2012). The Cdh15 gDMR was found to control transcription of an allele-specific RNA in the hypothalamus, but there was no evidence for imprinted expression at the other three loci. All four gDMRs again lost their parental mark through gains in methylation in most adult tissues, highlighting the crucial role of protection from de novo methylation for imprint stability. They proposed that such genes, which would include Fkbp6, Cdh15, Gpr1 and others, should be referred to as transient imprints. The subtlety of regulation of these loci led to the question of how functionally important this was. In a subsequent paper, they showed however that for the Gpr1 locus, DNA methylation did indeed play an important role in fine-tuning transcription levels (Duffie et al. 2014). At this locus, interestingly, the histone marks seem to play a secondary role.

In contrast to these transient imprints, the canonical imprinted loci maintain methylation differences at the gDMR even in tissues that do not express the associated gene (Woodfine et al. 2011, Court et al. 2014, Wang et al. 2014), highlighting the existence of mechanisms to (1) prevent demethylation of the methylated (usually maternal) allele and (2) protect the unmethylated (usually paternal) allele from gaining methylation. Studies comparing the sizes of DMR concluded that a certain degree of shrinkage occurs from the gametic state as the embryo matures (Court et al. 2014) but that the boundaries do not markedly shift upstream or downstream, consistent with a mechanism centred on the sequence determinants in the gDMRs.

\section{Possible role of other cytosine modifications at imprinted loci}

The dynamic changes in DNA methylation seen during early development are now known to be driven both by passive dilution through replication in the absence of maintenance activity, as well as active demethylation via the action of the three ten-eleven translocation (Tet) enzymes (Guo et al. 2014, Wang et al. 2014). The Tets have been shown to catalyse the oxidation of normal 5 -methylcytosine $(5 \mathrm{mC})$, first to 5-hydroxymethylation $(5 \mathrm{hmC})$, then to 5 -formlycystosine $(5 \mathrm{fC})$ and 5 -carboxycytosine $(5 \mathrm{caC})$, at which stage the modified nucleotide is excised from DNA by the base excision repair enzyme thymidine DNA glycosylase (TDG) or possibly removed through an as-yet uncharacterised 
decarboxylase activity (reviewed in Hahn et al. 2014). Active demethylation explains the rapid loss of $5 \mathrm{mC}$ in the pronuclei of the fertilised egg in the absence of replication, particularly notable for the male pronucleus, and lies behind much of the swift demethylation seen at some other time points such as germ cell specification and preimplantation development (reviewed in Hill et al. 2014). Blocking the action of the Tets thus prevents the demethylation at ICR in the germ cells required to reset the imprints, and it is only through the protective action of PGC7 (Nakamura et al. 2012, Szabó \& Pfeifer 2012) that imprints can be maintained pre implantation when Tet activity drives rapid demethylation at other methylated regions (Guo et al. 2014, Wang et al. 2014).

In addition to being an intermediate in the active demethylation pathway, however, there is some evidence that $5 \mathrm{hmC}$ may also act as a stable epigenetic mark in itself (Hahn et al. 2014). Support for this derives from the observations that $5 \mathrm{hmC}$ levels in brain are too high to be consistent with being an intermediate in active demethylation in the non-replicating neurons and that proteins with high affinities for $5 \mathrm{hmC}$, which may represent specific readers of this modification, appear to exist (lurlaro et al. 2013, Spruijt et al. 2013). Thus, $5 \mathrm{hmC}$ is frequently detected at high levels in neural tissues in the absence of $5 \mathrm{fC}$ and $5 \mathrm{caC}$ and may play an instructive role. Since it cannot be distinguished from $5 \mathrm{mC}$ by standard bisulfite modification and sequencing, it may contribute a substantial proportion of the DNA methylation reported at some loci. Examination of imprinted genes using methods that detect $5 \mathrm{hmC}$ have indicated however that the majority of methylation seen at ICR is indeed $5 \mathrm{mC}$ in adult tissues, though $5 \mathrm{hmC}$ is relatively enriched at imprinted loci compared to the levels elsewhere in the genome (Hernandez Mora et al. 2005). The $5 \mathrm{hmC}$ was present on the same allele as the $5 \mathrm{mC}$, suggesting to the authors that it might be a stable mark here and not a sign of active demethylation. However, it is possible that this might reflect a dynamic turnover of methyl groups here, since Zhang and colleagues recently showed that G9a/GLP was required to recruit de novo methyltransferases to counteract TET activity at imprinted ICR (Zhang et al. 2016). However, levels of oxidised methyl cytosine products at ICR were not measured directly in the latter experiments. Much of the $5 \mathrm{hmC}$ that was detected by Hernandez Mora and colleagues was in transcribed regions of imprinted genes, not ICR, in keeping with an earlier report for H19 (Nestor et al. 2012). Intriguingly, an association has been reported between 5hmC levels in H19 and smallfor-gestational-age babies (Piyasena et al. 2015).

Thus, while there is good evidence for high levels of $5 \mathrm{hmC}$ and other modified cytosines being seen at imprints during reprogramming, levels appear to be much lower in adult tissues except brain, and may be more related to transcription in the latter, since found in the gene bodies.

\section{Can somatic reprogramming of imprints occur?}

One of the key features of imprinted regions is their programming in the germ line, when the parental alleles are separated. Early work showed that in Dnmt1-/- ES cells (1 KO - Fig. 1B), imprints lost DNA methylation and could not recover it even when DNMT1 was restored using a cDNA $(1 \mathrm{KO}+1)$, unlike the rest of the genome. However, when the rescued ES cells were used to make mice, the imprints were restored following passage through the germline (Tucker et al. 1996). This is thought to be due to the imperviousness of imprints to the normal reprogramming events seen in the soma. Indeed, the inability to reprogram in somatic tissues is a key difference between the imprinted gDMRs and the other two classes of gDMR, namely those found in germline and brain genes (Borgel et al. 2010, Rutledge et al. 2014), whose methylation can be restored in $1 \mathrm{KO}+1$ cells (Fig. 1B). We and others have confirmed these results both in ES cells (Chen et al. 2003, Thakur et al. 2016) and in adult cell lines (Chen et al. 2003, Wernig et al. 2007) (Fig. 1B and C). Interestingly, imprints appear to be resistant to demethylation as well as remethylation: treatment of cells with $5^{\prime}$ Aza-2'deoxytidine (Aza) results in robust demethylation of most targets, but not imprints (O'Neill et al. 2018).

However, recently two ES cell systems have been described in which imprints can apparently be restored, breaking one of the main rules of imprinting. Wong and colleagues, working with UHRF1-deficient ES cells (Qi et al. 2015), found that most imprinted gDMRs lost methylation, as expected, since UHRF1 appears to be a vital cofactor for DNMT1 in somatic cells (Bostick et al. 2007, Sharif et al. 2007). Surprisingly however, they found that when they rescued these cells using a UHRF1 CDNA that not only was methylation restored on bulk DNA, but also is a subset of the imprinted loci showed recovery. In particular, the H19, Nnat and Dlk1 gDMRs showed some recovery of methylation, though not to WT levels, and ZFP57 binding was restored at 2/3 loci (Qi et al. 2015). While it would be reasonable to assume that an underlying chromatin mark might be retained, allowing restoration of methylation, there was no clear correlation between recovery and chromatin marks at the loci (Qi et al. 2015).

Using a different ES cell system, we too found somatic recovery of imprints could occur under some conditions. In cells lacking DNMT3A and DNMT3B (3abKO), imprinted gDMRs lost their parental allelespecific methylation to almost the same extent as in DNMT1-deficient cells. However, in contrast to rescue experiments in $1 \mathrm{KO}$ cells, when DNMT3A2 was added back to the 3 abKO cells, we found that DNA methylation was restored at most gDMRs examined (11/14), with many achieving levels similar to the WT cells (Fig. 1B). Results were confirmed using up to three different techniques (Thakur et al. 2016). 
Taken together, these two sets of results independently confirm that in some ES cell types, methylation can be restored on imprinted gDMRs outside of the germline opening the way for further exploration of the factors and signals that may be involved.

\section{Implications for reproductive biology}

\section{How many imprinted loci are there?}

In the index species mouse, where most data are available and there have been some dedicated searches, the number of verified imprinted loci remains relatively steady at around 150 . Despite a few highprofile studies suggesting more may exist, the number of genes with confirmed uniparental expression has not increased greatly. Many of the known imprinted genes in mouse (http://www.mousebook.org/imprintinggene-list (accessed 24/1/2018)) are also imprinted in human (http://igc.otago.ac.nz/1601 summarytable.pdf (accessed 24/1/2018)). A recent study by Wang et al. (2014) identified a small number of new germline DMR, for which uniparental methylation has been verified by ourselves or others (Thakur et al. 2016), but the effects on transcription are yet to be confirmed. Likewise a study in human by Court et al. (2014) using a combination of arrays and whole-genome bisulfite sequencing (WGBS - see below) added some new DMR. These were largely confined to known imprinted loci, although some were novel placenta-specific DMR. One caveat with the latter is that the differential methylation appears to have been established postnatally, which would require a radical rethink of mechanisms. However, some evidence exists to suggest that this may also occur in mouse (Wagschal \& Feil 2006).

In addition to the 'true' imprints, there are a number of 'transient' imprinted genes that show widespread imprinting in the early embryo that later becomes confined to one tissue (see 'Post-implantation changes' section above). This larger group of neuronal and germline genes have gDMRs in the early embryo that become erased post-implantation, largely through the de novo methylation of the unmethylated paternal allele (Borgel et al. 2010, Proudhon et al. 2012, Rutledge et al. 2014). These loci have not all been tested for uniparental expression in early development, but may contribute to parent-of-origin effects in early embryogenesis.

\section{How conserved are imprints in other species?}

Initial reports of imprinting in mouse were quickly followed by the investigation of corresponding human loci, and the subsequent discovery that at least one of the index loci $I G F 2 R$ was not imprinted in all humans, but may instead show polymorphic imprinting (Xu et al. 1993). As the number of well-characterised imprinted loci in mouse grew, the general trend was for the homologous locus in human to be imprinted, but with a number of notable exceptions (Hanna \& Kelsey 2014, Peters 2014). In general, though, the emerging complexity of imprint locus control has tended to discourage attempts to verify in detail in the second species, with an assumption of similarity being adopted on the whole unless forced to be re-evaluated due to clinical or experimental evidence.

Some early studies also tried to map the index imprinted loci in marsupials in order to test parental conflict theories as well as to investigate evolutionary mechanisms. This met with some success, despite the difficulty of the exercise. There is now support for an origin for imprinting at the time of divergence of marsupials (metatheria) and egg-laying mammals (montremes), which lack imprinting (Renfree et al. 2013). The oldest imprinted loci with a conserved DMR are H19 and PEG10, though a number of other imprinted genes such as IGF2R and PEG1 are also imprinted, but lack a conserved DMR. Many other loci appear to have acquired imprinting in eutheria (Renfree et al. 2013). PEG10 is a retroposon-derived gene, and it has long been suggested that there is a link between methylation at newly acquired retrotransposons and imprinting (Yoder et al. 1997). It is interesting in this context that rodentia are notable for having the highest number of imprinted loci and also a unique methyltransferase locus Dnmt3c, initially thought to be a pseudogene based on an early draft of the rat genome (Lees-Murdock et al. 2004) but now shown to produce a functional enzyme confined to the male rodent germline that appears dedicated to retroposon methylation (Barau et al. 2016).

\section{ART and imprints}

In livestock species, there has also been a lively interest in imprinted loci (O'Doherty et al. 2012), partly due to the widespread use of artificial reproduction techniques (ART), which are thought to be particularly associated with perturbed methylation and development including syndromes such as the aforementioned LOS (see above), enlarged placenta and perinatal death. These have been tied to changes in methylation at imprinted loci in a number of studies in cattle $\left(\mathrm{O}^{\prime}\right.$ Doherty et al. 2012, 2014). While studies in mouse have found substantial support for ART-induced alterations in imprints (Rivera et al. 2008, Denomme \& Mann 2012), in humans, any link between methylation changes at imprinted loci and standard IVF has been controversial, with most reviews of the area not able to fully exclude an effect on imprints or other epigenetically regulated loci (Grafodatskaya et al. 2013). However, the addition of large enough concentrations of inhibitors such as aphidicolin have conclusively been shown to alter the programmed demethylation of the genome (Guo et al. 2014) at the pronuclear stage, so 


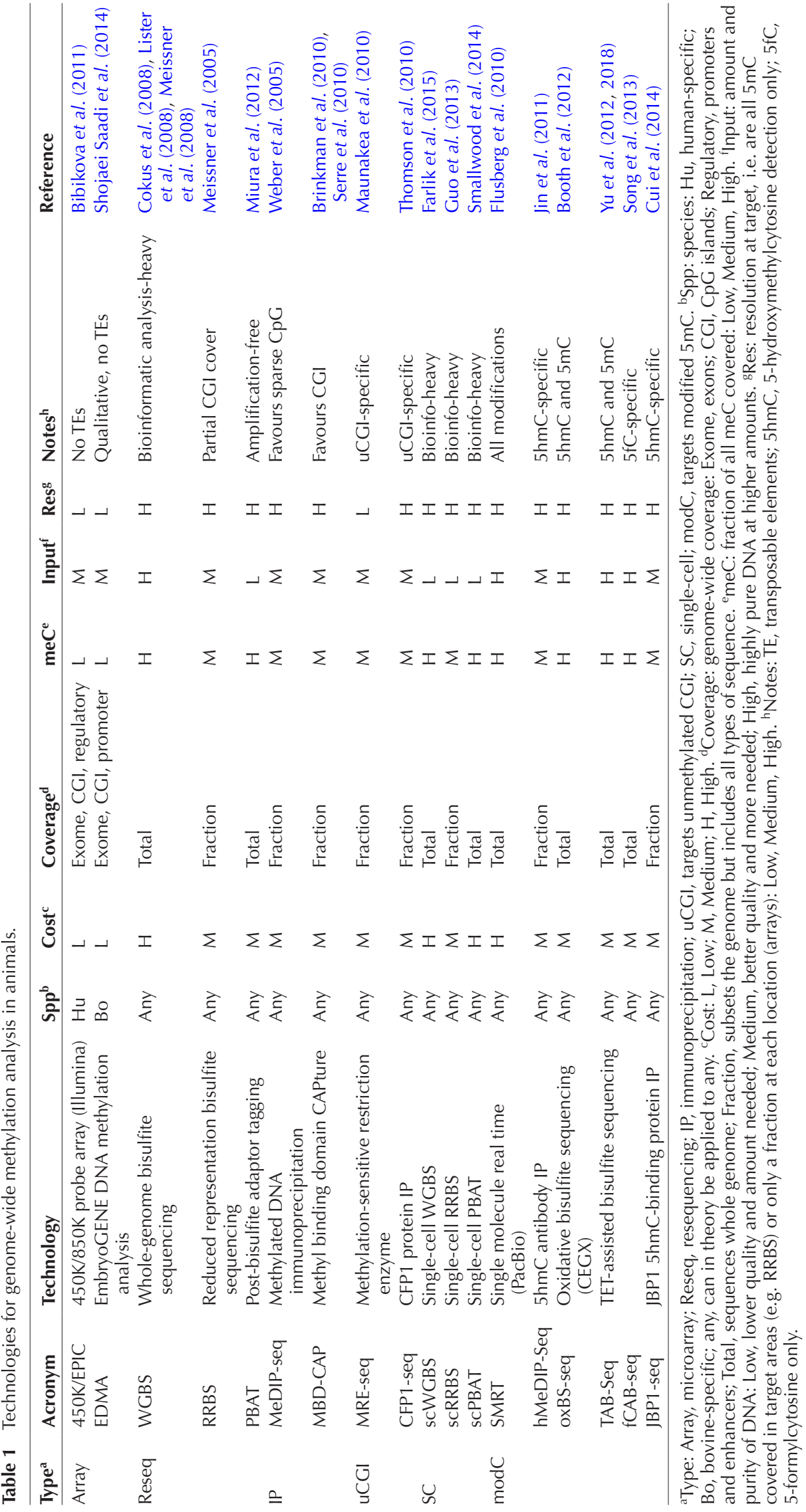


environmental perturbations of imprinting remain at least theoretically plausible.

\section{Use of sequencing technologies to investigate known and potential imprinted regions}

There have been a number of approaches taken to identify potentially imprinted genes and to more closely define the size of the imprint, partly dictated by the tools and approaches available in the differing species. In humans for example, microarrays have made assessing methylation easier, but low heterozygosity levels and incomplete data make assignment of parental allele and gametic imprints - even with resequencing approaches problematic, whereas in mice, no methylation arrays are available but interspecific crosses can be generated to maximise heterozygosity. Ruminants on the other hand have a long reproductive cycle and inter-strain hybrids are not commonly used, and with some exceptions, there are no arrays here either. For these reasons, resequencing approaches offer the most widely applicable tool (Table 1). While sequencing can be restrictive in cost, it represents a powerful discovery platform.

Wang and colleagues for example used WGBS to investigate the methylation status of the 54 imprinted DMR in the mouse genome (Wang et al. 2014), and in particular to sort unclassified DMR into gametic or somatic categories. They compared oocyte, sperm and early embryo, and began by confirming they could correctly sort all the DMR whose status was known (29) into gametic vs somatic types. They then used the same criteria to classify 25 imprinted DMRs whose status was unknown into gametic or somatic DMR, which is essential for determining where primary control of each locus is being exerted. At least four of these newly classified DMRs could subsequently be independently confirmed using a pyrosequencing-based assay (Thakur et al. 2016).

In humans, microarray technologies and in particular the Illumina EPIC array, have become so reliable in terms of assessing methylation levels quantitatively that confirmation by a second technology has become almost redundant. The low relative cost of the array makes it an attractive approach for initial screening and a comparison of uniparental disomies could correctly identify all 30 DMRs for which the array had probes (one DMR at MEG3/DLK1 is not covered). They additionally identified 21 novel putative imprints, 15 specific to placenta, albeit a number of them were at known imprinted loci already (Court et al. 2014). However, the low relative resolution of the array meant that they needed to use WGBS to accurately delineate the DMR.

Reliable standardised methylation microarrays are largely confined to humans, though the success of the $450 \mathrm{~K}$ and EPIC platforms has meant that Illumina appears to be considering a similar BeadChip array for mouse. An exception is cattle, where the EDMA array has been developed for assessing genome-wide methylation (Shojaei Saadi et al 2014), though this is based on cutting with methylation-sensitive restriction enzymes rather than oligos. While the array gives good internal consistency and technical reproducibility and could correctly identify methylation status at a number of imprinted regions in this species, it gives relative rather than absolute levels of methylation and is therefore difficult to correlate with outputs from many other assays (Desmet et al. 2016), though not all (Ispada et al. 2018). Whole-genome sequencing represents the gold standard for exploratory work and can definitively assess methylation across all sites. Confirming parental origin of the methylation mark requires heterozygous SNPs

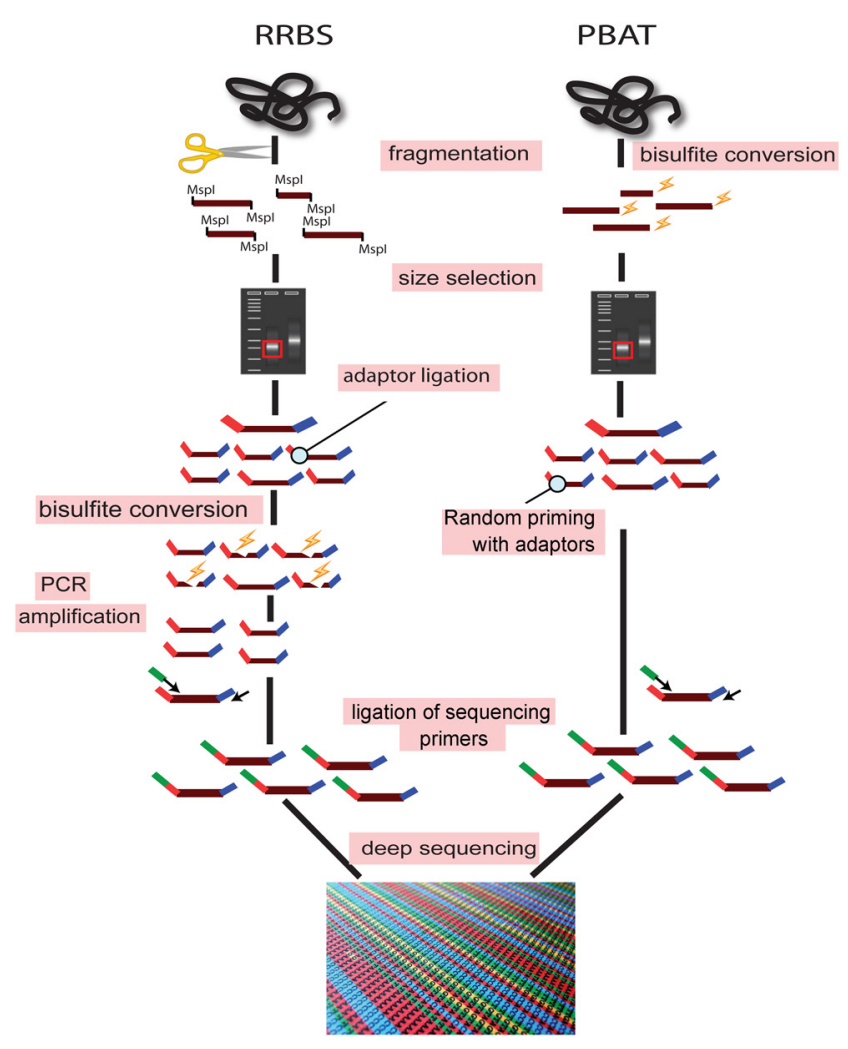

Figure 2 Schematic comparison of reduced representation bisulfite sequencing (RRBS) vs post-bisulfite adaptor tagging (PBAT). In RRBS (left), the DNA is initially fragmented by a methylation-insensitive restriction endonuclease such as $\mathrm{Mspl}$ to an optimal fragment size of between 400 and $600 \mathrm{bp}$, and this fraction isolated following gel electrophoresis or similar. Adaptors are ligated to these DNA fragments that are subsequently treated through bisulfite conversion to convert unmethylated cytosines to thymines for the differential readout. Amplification is carried out using primers specific to the adaptor sequences, but there is substantial loss of sample at this point due to strand breakage (flashes) between adaptors caused by bisulfite. PBAT (right) skips the initial enzyme digestion and instead takes advantage of the bisulfite-induced breakage to fragment the DNA here. Instead of PCR, the adaptors are used for two rounds of random primer extension, which serves to produce numerous reads from a small amount of input genomic DNA. 
however. While Liu and colleagues could find sufficient variation in an inter-strain cross for mice (Wang et al. 2014), generating cross-bred cattle is not trivial given cost implications and slow reproductive times and most reported work in the area does not feature such animals.

An alternative, more widely applicable and costeffective approach for assessing methylation is to subset the genome and do targeted resequencing. Reduced representation bisulfite sequencing has been the most extensively used method in this category so far (Meissner et al. 2005), but is being superseded by post-bisulfite adaptor tagging (PBAT) (Miura et al. 2012), which appears to offer improvements in yield and efficiency, particularly when starting with small amounts of material such as oocytes (Smallwood et al. 2014) (Fig. 2). Apart from cost considerations, a significant bottleneck for resequencing-based analyses is the extensive bioinformatic analysis required, with concomitant need for higher-specification computing hardware, local network clusters and data warehousing, all adding substantial capital and human resource costs to the equation (Lewitter et al. 2009). While this has resulted in the majority of such work being undertaken at large central institutes that have developed the required infrastructure, often with national support, there remains a niche for smaller players out-sourcing the sequencing to larger centres with surplus capacity and who may in future also be able to avail of cloud-based storage and analysis capabilities (Liu et al. 2014).

Another point to consider here is that some species that may be of interest for biologists wishing to understand the origins or phylogenetic reach of imprinting may not be sequenced yet. In cases where a reference genome framework is unavailable, assembling sequence reads and defining variation become considerably more challenging (Cahais et al. 2012).

Finally, the impact of third-generation sequencing technologies is yet to be fully felt, given that this market is currently in flux and no clear front-runner appears yet to have emerged. Current technologies require a separate sequence library for each type of cytosine modification for example ( $\mathrm{meC}, 5 \mathrm{hmC}, 5 \mathrm{fC}, 5 \mathrm{caC}$ ) (Yu et al. 2012), whereas certain new approaches (Table 1) such as PacBio's technology have the capability to also call methylated bases while sequencing, obviating the need for multiple sequence sets (Lister \& Ecker 2009).

\section{Conclusions and future prospects}

Imprinting clearly plays an important role in body size determination and nutrient transfer to the young, making assessment of methylation at key loci a useful tool for reproductive biologists and breeders alike. Despite the improvement in technologies for assessing and delineating imprinting, the number of verified imprinted loci has not increased very significantly. However, our understanding of the mechanisms by which these regions are established and maintained in early life, as well as the contexts in which some plasticity in imprinting may occur, have greatly increased. We can look forward to further insights from comparative genomic approaches based on the increasing application of sequencing technologies to an ever-expanding range of organisms, including the so far rather surprisingly neglected livestock species, which play such an important role in human food production and welfare.

\section{Declaration of interest}

The authors declare that there is no conflict of interest that could be perceived as prejudicing the impartiality of this review.

\section{Funding}

The authors' work was supported in part by the Medical Research Council (grant number MR/J007773/1) and a grant jointly funded by the ESRC/BBSRC (grant number ES/N000323/1).

\section{Acknowledgements}

The authors thank members of the Walsh lab for helpful comments and apologize to colleagues whose work could not be cited owing to length limitations.

\section{References}

Allen WR 1969 Factors influencing pregnant mare serum gonadotrophin production. Nature 223 64-65. (https://doi.org/10.1038/223064a0)

Aravind L \& Koonin EV 2000 SAP - a putative DNA-binding motif involved in chromosomal organization. Trends in Biochemical Sciences 25 112-114. (https://doi.org/10.1016/S0968-0004(99)01537-6)

Barau J, Teissandier A, Zamudio N, Roy S, Nalesso V, Herault Y, Guillou F \& Bourc'his D 2016 The DNA methyltransferase DNMT3C protects male germ cells from transposon activity. Science 354 909-912. (https://doi. org/10.1126/science.aah5143)

Barlow DP \& Bartolomei MS 2014 Genomic imprinting in mammals. Cold Spring Harbor Perspectives in Biology 6 (https://doi.org/10.1101/ cshperspect.a018382)

Bartolomei MS \& Ferguson-Smith AC 2011 Mammalian genomic imprinting. Cold Spring Harbor Perspectives in Biology 3 a018382. (https://doi.org/10.1101/cshperspect.a002592)

Barton SC, Surani MA \& Norris ML 1984 Role of paternal and maternal genomes in mouse development. Nature 311 374-376. (https://doi. org/10.1038/311374a0)

Bell AC \& Felsenfeld G 2000 Methylation of a CTCF-dependent boundary controls imprinted expression of the Igf2 gene. Nature 405 482-485. (https://doi.org/10.1038/35013100)

Bibikova M, Barnes B, Tsan C, Ho V, Klotzle B, Le JM, Delano D, Zhang L, Schroth GP, Gunderson KL et al. 2011 High density DNA methylation array with single CpG site resolution. Genomics 98 288-295. (https:// doi.org/10.1016/j.ygeno.2011.07.007)

Bidwell CA, Waddell JN, Taxis TM, Yu H, Tellam RL, Neary MK \& Cockett NE 2014 New insights into polar overdominance in callipyge sheep. Animal Genetics 45 (Supplement 1) 51-61. (https://doi.org/10.1111/age.12132)

Bird AP 1987 CpG islands as gene markers in the vertebrate nucleus. Trends in Genetics 3 342-347. (https://doi.org/10.1016/01689525(87)90294-0)

Booth MJ, Branco MR, Ficz G, Oxley D, Krueger F, Reik W \& Balasubramanian S 2012 Quantitative sequencing of 5-methylcytosine and 5-hydroxymethylcytosine at single-base resolution. Science 336 934-937. (https://doi.org/10.1126/science.1220671) 
Borgel J, Guibert S, Li Y, Chiba H, Schubeler D, Sasaki H, Forne T \& Weber M 2010 Targets and dynamics of promoter DNA methylation during early mouse development. Nature Genetics 42 1093-1100. (https://doi.org/10.1038/ng.708)

Bostick M, Kyong Kim J, Esteve P, Clark A \& Pradhan S 2007 UHRFI plays a role in maintaining DNA methylation in mammalian cells. Science 317 1760-1764. (https://doi.org/10.1126/science.1147939)

Brinkman AB, Simmer F, Ma K, Kaan A, Zhu J \& Stunnenberg HG 2010 Whole-genome DNA methylation profiling using MethylCap-seq. Methods 52 232-236. (https://doi.org/10.1016/j.ymeth.2010.06.012)

Buiting K 2010 Prader-Willi syndrome and Angelman syndrome. American Journal of Medical Genetics: Part C, Seminars in Medical Genetics 154C 365-376. (https://doi.org/10.1002/ajmg.c.30273)

Cahais V, Gayral P, Tsagkogeorga G, Melo-Ferreira J, Ballenghien M, Weinert L, Chiari Y, Belkhir K, Ranwez V \& Galtier N 2012 Referencefree transcriptome assembly in non-model animals from next-generation sequencing data. Molecular Ecology Resources 12 834-845. (https://doi. org/10.1111/j.1755-0998.2012.03148.x)

Chen T, Ueda Y, Dodge JE, Wang Z \& Li E 2003 Establishment and maintenance of genomic methylation patterns in mouse embryonic stem cells by Dnmt3a and Dnmt3b. Molecular and Cellular Biology 23 5594-5605. (https://doi.org/10.1128/MCB.23.16.5594-5605.2003)

Chen Z, Robbins KM, Wells KD \& Rivera RM 2013 Large offspring syndrome: a bovine model for the human loss-of-imprinting overgrowth syndrome Beckwith-Wiedemann. Epigenetics 8 591-601. (https://doi. org/10.4161/epi.24655)

Chen Z, Hagen DE, Elsik CG, Ji T, Morris CJ, Moon LE \& Rivera RM 2015 Characterization of global loss of imprinting in fetal overgrowth syndrome induced by assisted reproduction. PNAS 112 4618-4623. (https://doi.org/10.1073/pnas.1422088112)

Ciccone DN, Su H, Hevi S, Gay F, Lei H, Bajko J, Xu G, Li E \& Chen T 2009 KDM1B is a histone H3K4 demethylase required to establish maternal genomic imprints. Nature 461 415-418. (https://doi.org/10.1038/ nature08315)

Cokus SJ, Feng S, Zhang X, Chen Z, Merriman B, Haudenschild CD, Pradhan S, Nelson SF, Pellegrini M \& Jacobsen SE 2008 Shotgun bisulphite sequencing of the Arabidopsis genome reveals DNA methylation patterning. Nature 452 215-219. (https://doi.org/10.1038/ nature06745)

Court F, Tayama C, Romanelli V, Martin-Trujillo A, Iglesias-Platas I, Okamura K, Sugahara N, Simon C, Moore H, Harness JV et al. 2014 Genome-wide parent-of-origin DNA methylation analysis reveals the intricacies of human imprinting and suggests a germline methylationindependent mechanism of establishment. Genome Research 24 554-569. (https://doi.org/10.1101/gr.164913.113)

Cui L, Chung TH, Tan D, Sun X \& Jia XY 2014 JBP1-seq: a fast and efficient method for genome-wide profiling of 5hmC. Genomics 104 368-375. (https://doi.org/10.1016/j.ygeno.2014.08.023)

Curley JP, Pinnock SB, Dickson SL, Thresher R, Miyoshi N, Surani MA \& Keverne EB 2005 Increased body fat in mice with a targeted mutation of the paternally expressed imprinted gene Peg3. FASEB Journal 19 1302-1304. (https://doi.org/10.1096/fj.04-3216fje)

Denomme MM \& Mann MR 2012 Genomic imprints as a model for the analysis of epigenetic stability during assisted reproductive technologies. Reproduction 144 393-409. (https://doi.org/10.1530/REP-12-0237)

Desmet KL, Van Hoeck V, Gagne D, Fournier E, Thakur A, O'Doherty AM, Walsh CP, Sirard MA, Bols PE \& Leroy JL 2016 Exposure of bovine oocytes and embryos to elevated non-esterified fatty acid concentrations: integration of epigenetic and transcriptomic signatures in resultant blastocysts. BMC Genomics 17 1004-1022. (https://doi.org/10.1186/ s12864-016-3366-y)

Duffie R, Ajjan S, Greenberg MV, Zamudio N, Escamilla del Arenal M, Iranzo J, Okamoto I, Barbaux S, Fauque P \& Bourc'his D 2014 The Gpr1/Zdbf2 locus provides new paradigms for transient and dynamic genomic imprinting in mammals. Genes and Development 28 463-478.

Farlik M, Sheffield NC, Nuzzo A, Datlinger P, Schonegger A, Klughammer I \& Bock C 2015 Single-cell DNA methylome sequencing and bioinformatic inference of epigenomic cell-state dynamics. Cell Reports 10 1386-1397. (https://doi.org/10.1016/j.celrep.2015.02.001)

Flusberg BA, Webster DR, Lee JH, Travers KJ, Olivares EC, Clark TA, Korlach J \& Turner SW 2010 Direct detection of DNA methylation during single-molecule, real-time sequencing. Nature Methods 7 461-465. (https://doi.org/10.1038/nmeth.1459)

Freking BA, Keele JW, Nielsen MK, Leymaster KA 2002a Evaluation of the ovine callipyge locus: II. Genotypic effects on growth, slaughter, and carcass traits. Journal of Animal Science 76 2549-2559 (https://doi. org/10.2527/1998.76102549x)

Freking BA, Murphy SK, Wylie AA, Rhodes SJ, Keele JW, Leymaster KA, Jirtle RL \& Smith TP 2002b Identification of the single base change causing the callipyge muscle hypertrophy phenotype, the only known example of polar overdominance in mammals. Genome Research $\mathbf{1 2}$ 1496-1506. (https://doi.org/10.1101/gr.571002)

Grafodatskaya D, Cytrynbaum C \& Weksberg R 2013 The health risks of ART. EMBO Reports 14 129-135. (https://doi.org/10.1038/ embor.2012.222)

Guillemot F, Caspary T, Tilghman SM, Copeland NG, Gilbert DJ, Jenkins NA, Anderson DJ, Joyner AL, Rossant J \& Nagy A 1995 Genomic imprinting of Mash2, a mouse gene required for trophoblast development. Nature Genetics 9 235-242. (https://doi.org/10.1038/ng0395-235)

Guo H, Zhu P, Wu X, Li X, Wen L \& Tang F 2013 Single-cell methylome landscapes of mouse embryonic stem cells and early embryos analyzed using reduced representation bisulfite sequencing. Genome Research $\mathbf{2 3}$ 2126-2135. (https://doi.org/10.1101/gr.161679.113)

Guo F, Li X, Liang D, Li T, Zhu P, Guo H, Wu X, Wen L, Gu TP, Hu B et al. 2014 Active and passive demethylation of male and female pronuclear DNA in the mammalian zygote. Cell Stem Cell 15 447-459. (https://doi. org/10.1016/j.stem.2014.08.003)

Hahn MA, Szabo PE \& Pfeifer GP 2014 5-Hydroxymethylcytosine: a stable or transient DNA modification? Genomics 104 314-323. (https://doi. org/10.1016/j.ygeno.2014.08.015)

Haig D \& Graham C 1991 Genomic imprinting and the strange case of the insulin-like growth factor II receptor. Cell 64 1045-1046. (https://doi. org/10.1016/0092-8674(91)90256-X)

Hanna CW \& Kelsey G 2014 The specification of imprints in mammals. Heredity 113 176-183. (https://doi.org/10.1038/hdy.2014.54)

Hanna CW, Penaherrera MS, Saadeh H, Andrews S, McFadden DE, Kelsey G \& Robinson WP 2016 Pervasive polymorphic imprinted methylation in the human placenta. Genome Research 26 756-767. (https://doi.org/10.1101/gr.196139.115)

Hark AT, Schoenherr CJ, Katz DJ, Ingram RS, Levorse JM \& Tilghman SM 2000 CTCF mediates methylation-sensitive enhancer-blocking activity at the H19/lgf2 locus. Nature 405 486-489 (https://doi. org/10.1038/35013106)

Hernandez Mora JR, Sanchez-Delgado M, Petazzi P, Moran S, Esteller M, Iglesias-Platas I \& Monk D 2005 Profiling of oxBS-450K 5 -hydroxymethylcytosine in human placenta and brain reveals enrichment at imprinted loci. Epigenetics 13 182-191. (https://doi.org/1 0.1080/15592294.2017.1344803)

Hill PW, Amouroux R \& Hajkova P 2014 DNA demethylation, Tet proteins and 5-hydroxymethylcytosine in epigenetic reprogramming: an emerging complex story. Genomics 104 324-333. (https://doi.org/10.1016/j. ygeno.2014.08.012)

Ispada J, de Lima CB, Sirard MA, Fontes PK, Nogueira MFG, Annes K \& Milazzotto MP 2018 Genome-wide screening of DNA methylation in bovine blastocysts with different kinetics of development. Epigenetics and Chromatin 11 1. (https://doi.org/10.1186/s13072-017-0171-z)

Iurlaro M, Ficz G, Oxley D, Raiber E, Bachman M, Booth MJ, Andrews S, Balasubramanian S \& Reik W 2013 A screen for hydroxymethylcytosine and formyl cytosine binding proteins suggests functions in transcription and chromatin regulation. Genome Biology 14 R119. (https://doi. org/10.1186/gb-2013-14-10-r119)

Jeon JT, Carlborg O, Tornsten A, Giuffra E, Amarger V, Chardon P, Andersson-Eklund L, Andersson K, Hansson I, Lundstrom K et al. 1999 A paternally expressed QTL affecting skeletal and cardiac muscle mass in pigs maps to the IGF2 locus. Nature Genetics 21 157-158. (https:// doi.org/10.1038/5938)

Jin SG, Wu X, Li AX \& Pfeifer GP 2011 Genomic mapping of 5-hydroxymethylcytosine in the human brain. Nucleic Acids Research 39 5015-5024. (https://doi.org/10.1093/nar/gkr120)

Kato Y, Kaneda M, Hata K, Kumaki K, Hisano M, Kohara Y, Okano M, Li E, Nozaki M \& Sasaki H 2007 Role of the Dnmt3 family in de novo methylation of imprinted and repetitive sequences during male germ cell 
development in the mouse. Human Molecular Genetics 16 2272-2280. (https://doi.org/10.1093/hmg/ddm179)

Keverne EB \& Curley JP 2008 Epigenetics, brain evolution and behaviour. Frontiers in Neuroendocrinology 29 398-412. (https://doi.org/10.1016/j. yfrne.2008.03.001)

Kobayashi H, Sakurai T, Imai M, Takahashi N, Fukuda A, Yayoi O, Sato S, Nakabayashi K, Hata K, Sotomaru Y et al. 2012 Contribution of intragenic DNA methylation in mouse gametic DNA methylomes to establish oocyte-specific heritable marks. PLoS Genetics 8 e1002440. (https://doi.org/10.1371/journal.pgen.1002440)

Lees-Murdock DJ, McLoughlin GA, McDaid JR, Quinn LM, O'Doherty A, Hiripi L, Hack CJ \& Walsh CP 2004 Identification of 11 pseudogenes in the DNA methyltransferase gene family in rodents and humans and implications for the functional loci. Genomics 84 193-204. (https://doi. org/10.1016/j.ygeno.2004.02.004)

Lewitter F, Rebhan M, Richter B \& Sexton D 2009 The need for centralization of computational biology resources. PLoS Computational Biology 5 e1000372. (https://doi.org/10.1371/journal.pcbi.1000372)

Li X, Ito M, Zhou F, Youngson N, Zuo X, Leder P \& Ferguson-Smith AC 2008 A maternal-zygotic effect gene, Zfp57, maintains both maternal and paternal imprints. Developmental Cell 15 547-557. (https://doi. org/10.1016/j.devcel.2008.08.014)

Lister R \& Ecker JR 2009 Finding the fifth base: genome-wide sequencing of cytosine methylation. Genome Research 19 959-966. (https://doi. org/10.1101/gr.083451.108)

Lister R, O'Malley RC, Tonti-Filippini J, Gregory BD, Berry CC, Millar AH \& Ecker JR 2008 Highly integrated single-base resolution maps of the epigenome in Arabidopsis. Cell 133 523-536. (https://doi.org/10.1016/j. cell.2008.03.029)

Liu B, Madduri RK, Sotomayor B, Chard K, Lacinski L, Dave UJ, Li J, Liu C \& Foster IT 2014 Cloud-based bioinformatics workflow platform for large-scale next-generation sequencing analyses. Journal of Biomedical Informatics 49 119-133 (https://doi.org/10.1016/j.jbi.2014.01.005)

Mackay DJ, Callaway JL, Marks SM, White HE, Acerini CL, Boonen SE, Dayanikli P, Firth HV, Goodship JA, Haemers AP et al. 2008 Hypomethylation of multiple imprinted loci in individuals with transient neonatal diabetes is associated with mutations in ZFP57. Nature Genetics 40 949-951. (https://doi.org/10.1038/ng.187)

Markljung E, Jiang L, Jaffe JD, Mikkelsen TS, Wallerman O, Larhammar M, Zhang X, Wang L, Saenz-Vash V, Gnirke A et al. 2009 ZBED6, a novel transcription factor derived from a domesticated DNA transposon regulates IGF2 expression and muscle growth. PLoS Biology 7 e1000256. (https://doi.org/10.1371/journal.pbio.1000256)

Maunakea AK, Nagarajan RP, Bilenky M, Ballinger TJ, D'Souza C, Fouse SD, Johnson BE, Hong C, Nielsen C, Zhao Y et al. 2010 Conserved role of intragenic DNA methylation in regulating alternative promoters. Nature 466 253-257. (https://doi.org/10.1038/nature09165)

Meissner A, Gnirke A, Bell GW, Ramsahoye B, Lander ES \& Jaenisch R 2005 Reduced representation bisulfite sequencing for comparative high-resolution DNA methylation analysis. Nucleic Acids Research 33 5868-5877. (https://doi.org/10.1093/nar/gki901)

Meissner A, Mikkelsen TS, Gu H, Wernig M, Hanna J, Sivachenko A, Zhang X, Bernstein BE, Nusbaum C, Jaffe DB et al. 2008 Genome-scale DNA methylation maps of pluripotent and differentiated cells. Nature 454 766-770. (https://doi.org/10.1038/nature07107)

Messerschmidt DM, de Vries W, Ito M, Solter D, Ferguson-Smith A \& Knowles BB 2012 Trim28 is required for epigenetic stability during mouse oocyte to embryo transition. Science 335 1499-1502. (https:// doi.org/10.1126/science.1216154)

Miura F, Enomoto Y, Dairiki R \& Ito T 2012 Amplification-free wholegenome bisulfite sequencing by post-bisulfite adaptor tagging. Nucleic Acids Research 40 e136. (https://doi.org/10.1093/nar/gks454)

Moore T \& Haig D 1991 Genomic imprinting in mammalian development: a parental tug-of-war. Trends in Genetics 7 45-49. (https://doi. org/10.1016/0168-9525(91)90230-N)

Nakamura T, Arai Y, Umehara H, Masuhara M, Kimura T, Taniguchi H, Sekimoto T, Ikawa M, Yoneda Y, Okabe M et al. 2007 PGC7/Stella protects against DNA demethylation in early embryogenesis. Nature Cell Biology 9 64-71. (https://doi.org/10.1038/ncb1519)

Nakamura T, Liu YJ, Nakashima H, Umehara H, Inoue K, Matoba S, Tachibana M, Ogura A, Shinkai Y \& Nakano T 2012 PGC7 binds histone
$\mathrm{H} 3 \mathrm{~K} 9 \mathrm{me} 2$ to protect against conversion of $5 \mathrm{mC}$ to $5 \mathrm{hmC}$ in early embryos. Nature 486 415-419 (https://doi.org/10.1038/nature11093)

Nestor CE, Ottaviano R, Reddington J, Sproul D, Reinhardt D, Dunican D, Katz E, Dixon JM, Harrison DJ \& Meehan RD 2012 Tissue type is a major modifier of the $5^{\prime}$-hydroxymethylcytosine content of human genes. Genome Research 22 467-477. (https://doi.org/10.1101/gr.126417.111) O'Doherty A, O'Shea LC \& Fair T 2012 Bovine DNA methylation imprints are established in an oocyte size-specific manner, which are coordinated with the expression of the DNMT3 family proteins. Biology of Reproduction 86 1-10. (https://doi.org/10.1095/biolreprod.111.094946)

O'Doherty A, O'Gorman A, al Naib A, Brennan L, Daly E, Duffy P \& Fair T 2014 Negative energy balance affects imprint stability in oocytes recovered from postpartum dairy cows. Genomics 104 177-185. (https:// doi.org/10.1016/j.ygeno.2014.07.006)

O'Neill KM, Irwin RE, Mackin SJ, Thursby SJ, Thakur A, Bertens C, Masala L, Loughery JEP, McArt DG \& Walsh CP 2018 Depletion of DNMT1 in differentiated human cells highlights key classes of sensitive genes and an interplay with polycomb repression. Epigenetics and Chromatin 11 12. (https://doi.org/10.1186/s13072-018-0182-4)

Ooi SK, Qiu C, Bernstein E, Li K, Jia D, Yang Z, Erdjument-Bromage H, Tempst P, Lin SP, Allis CD et al. 2007 DNMT3L connects unmethylated lysine 4 of histone $\mathrm{H} 3$ to de novo methylation of DNA. Nature 448 714-717. (https://doi.org/10.1038/nature05987)

Payer B, Saitou M, Barton SC, Thresher R, Dixon JPC, Zahn WH, Cartlon MBL, Nakano T \& Surani MA 2003 Stella is a maternal effect gene required for normal early development in mice. Current Biology $\mathbf{1 3}$ 2110-2117. (https://doi.org/10.1016/j.cub.2003.11.026)

Peters J 2014 The role of genomic imprinting in biology and disease: an expanding view. Nature Reviews Genetics 15 517-530. (https://doi. org/10.1038/nrg3766)

Piyasena C, Reynolds RM, Khulan B, Seckl JR, Menon G \& Drake AJ 2015 Placental 5-methylcytosine and 5-hydroxymethylcytosine patterns associate with size at birth. Epigenetics 10 692-697. (https://doi.org/10. 1080/15592294.2015.1062963)

Prickett AR, Barkas N, McCole RB, Hughes S, Amante SM, Schulz R \& Oakey RJ 2013 Genome-wide and parental allele-specific analysis of CTCF and cohesin DNA binding in mouse brain reveals a tissuespecific binding pattern and an association with imprinted differentially methylated regions. Genome Research 23 1624-1635. (https://doi. org/10.1101/gr.150136.112)

Proudhon C, Duffie R, Ajjan S, Cowley M, Iranzo J, Carbajosa G, Saadeh H, Holland ML, Oakey RJ, Rakyan VK et al. 2012 Protection against de novo methylation is instrumental in maintaining parentof-origin methylation inherited from the gametes. Molecular Cell $\mathbf{4 7}$ 909-920 (https://doi.org/10.1016/j.molcel.2012.07.010)

Qi S, Wang Z, Li P, Wu Q, Shi T, Li J \& Wong J 2015 Non-germ line restoration of genomic imprinting for a small subset of imprinted genes in ubiquitin-like PHD and RING finger domain-containing 1 (Uhrf1) null mouse embryonic stem cells. Journal of Biological Chemistry 290 14181-14191. (https://doi.org/10.1074/jbc.M114.626697)

Quenneville S, Verde G, Corsinotti A, Kapopoulou A, Jakobsson J, Offner S, Baglivo I, Pedone PV, Grimaldi G, Riccio A et al. 2011 In embryonic stem cells, ZFP57/KAP1 recognize a methylated hexanucleotide to affect chromatin and DNA methylation of imprinting control regions. Molecular Cell 44 361-372. (https://doi.org/10.1016/j.molcel.2011.08.032)

Renfree MB, Suzuki S \& Kaneko-Ishino T 2013 The origin and evolution of genomic imprinting and viviparity in mammals. Philosophical Transactions of the Royal Society of London: Series B, Biological Sciences 368 20120151. (https://doi.org/10.1098/rstb.2012.0151)

Rivera RM, Stein P, Weaver JR, Mager J, Schultz RM \& Bartolomei MS 2008 Manipulations of mouse embryos prior to implantation result in aberrant expression of imprinted genes on day 9.5 of development. Human Molecular Genetics 17 1-14. (https://doi.org/10.1093/hmg/ ddm280)

Rutledge CE, Thakur A, O'Neill KM, Irwin RE, Sato S, Hata K \& Walsh CP 2014 Ontogeny, conservation and functional significance of maternally inherited DNA methylation at two classes of non-imprinted genes. Development 141 1313-1323. (https://doi.org/10.1242/dev.104646)

Sato M, Kimura T, Kurokawa K, Fujita Y, Abe K, Masuhara M, Yasunaga T, Ryo A, Yamamoto M \& Nakano T 2002 Identification of PGC7, a new gene expressed specifically in preimplantation embryos and germ cells. 
Mechanisms of Development 113 91-94. (https://doi.org/10.1016/ S0925-4773(02)00002-3)

Serre D, Lee BH \& Ting AH 2010 MBD-isolated genome sequencing provides a high-throughput and comprehensive survey of DNA methylation in the human genome. Nucleic Acids Research 38 391-399. (https://doi.org/10.1093/nar/gkp992)

Sharif J, Muto M, Takebayashi S, Suetake I, Iwamatsu A, Endo TA, Shinga J, Mizutani-Koseki Y, Toyoda T, Okamura K et al. 2007 The SRA protein Np95 mediates epigenetic inheritance by recruiting Dnmt1 to methylated DNA. Nature 450 908-912. (https://doi.org/10.1038/nature06397)

Shirane K, Toh H, Kobayashi H, Miura F, Chiba H, Ito T, Kono T \& Sasaki H 2013 Mouse oocyte methylomes at base resolution reveal genome-wide accumulation of non-CpG methylation and role of DNA methyltransferases. PLoS Genetics 9 e1003439. (https://doi.org/10.1371/ journal.pgen.1003439)

Shojaei Saadi HA, O'Doherty AM, Gagne D, Fournier E, Grant JR, Sirard MA \& Robert C 2014 An integrated platform for bovine DNA methylome analysis suitable for small samples. BMC Genomics 15 451-468. (https://doi.org/10.1186/1471-2164-15-451)

Sleutels F, Zwart R \& Barlow DP 2002 The non-coding Air RNA is required for silencing autosomal imprinted genes. Nature 415 810-813. (https:// doi.org/10.1038/415810a)

Smallwood SA, Tomizawa S, Krueger F, Ruf N, Carli N, Segonds-Pichon A, Sato S, Hata K, Andrews SR \& Kelsey G 2011 Dynamic CpG island methylation landscape in oocytes and preimplantation embryos. Nature Genetics 43 811-814. (https://doi.org/10.1038/ng.864)

Smallwood SA, Lee HJ, Angermueller C, Krueger F, Saadeh H, Peat J, Andrews SR, Stegle O, Reik W \& Kelsey G 2014 Single-cell genomewide bisulfite sequencing for assessing epigenetic heterogeneity. Nature Methods 11 817-820. (https://doi.org/10.1038/nmeth.3035)

Song CX, Szulwach KE, Dai Q, Fu Y, Mao SQ, Lin L, Street C, Li Y, Poidevin M, Wu HC 2013 Genome-wide profiling of 5-formylcytosine reveals its roles in epigenetic priming. Cell 153 678-691. (https://doi. org/10.1016/j.cell.2013.04.001)

Spruijt CG, Gnerlich F, Smits AH, Pfaffeneder T, Jansen PW, Bauer C, Munzel M, Wagner M, Muller M, Khan F et al. 2013 Dynamic readers for 5-(hydroxy)methylcytosine and its oxidized derivatives. Cell 152 1146-1159. (https://doi.org/10.1016/j.cell.2013.02.004)

Strogantsev R, Krueger F, Yamazawa K, Shi H, Gould P, GoldmanRoberts M, McEwen K, Sun B, Pedersen R \& Ferguson-Smith AC 2015 Allele-specific binding of ZFP57 in the epigenetic regulation of imprinted and non-imprinted monoallelic expression. Genome Biology 16 112-119. (https://doi.org/10.1186/s13059-015-0672-7)

Szabó PE \& Pfeifer GP 2012 H3K9me2 attracts PGC7 in the zygote to prevent Tet3-mediated oxidation of 5-methylcytosine. Journal of Molecular Cell Biology 4 427-429. (https://doi.org/10.1093/jmcb/ mjs038)

Thakur A, Mackin SJ, Irwin RE, $\mathrm{O}^{\prime}$ Neill KM, Pollin G \& Walsh C 2016 Widespread recovery of methylation at gametic imprints in hypomethylated mouse stem cells following rescue with DNMT3A2. Epigenetics and Chromatin 9 53-67. (https://doi.org/10.1186/s13072016-0104-2)

Thomson JP, Skene PJ, Selfridge J, Clouaire T, Guy J, Webb S, Kerr AR, Deaton A, Andrews R, James KD et al. 2010 CpG islands influence chromatin structure via the CpG-binding protein Cfp1. Nature 464 1082-1086. (https://doi.org/10.1038/nature08924)

Tucker KL, Beard C, Dausmann J, Jackson-Grusby L, Laird PW, Lei H, Li E \& Jaenisch R 1996 Germ-line passage is required for establishment of methylation and expression patterns of imprinted but not of nonimprinted genes. Genes and Development 10 1008-1020. (https:// doi.org/10.1101/gad.10.8.10080)

Van Laere AS, Nguyen M, Braunschweig M, Nezer C, Collette C, Moreau L, Archibald AL, Haley CS, Buys N, Tally M et al. 2003 A regulatory mutation in IGF2 causes a major QTL effect on muscle growth in the pig. Nature 425 832-836. (https://doi.org/10.1038/nature02064)

Wagschal A \& Feil R 2006 Genomic imprinting in the placenta. Cytogenetic and Genome Research 113 90-98. (https://doi.org/10.1159/000090819)
Walsh C, Glaser A, Fundele R, Ferguson-Smith A, Barton S, Surani MA \& Ohlsson R 1994 The non-viability of uniparental mouse conceptuses correlates with the loss of the products of imprinted genes. Mechanisms of Development 46 55-62. (https://doi.org/10.1016/09254773(94)90037-X)

Wang X, Miller DC, Clark AG \& Antczak DF 2012 Random X inactivation in the mule and horse placenta. Genome Research 22 1855-1863. (https://doi.org/10.1101/gr.138487.112)

Wang X, Miller DC, Harman R, Antczak DF \& Clark AG 2013 Paternally expressed genes predominate in the placenta. PNAS 110 10705-10710. (https://doi.org/10.1073/pnas.1308998110)

Wang L, Zhang J, Duan J, Gao X, Zhu W, Lu X, Yang L, Zhang J, Li G, Ci W et al. 2014 Programming and inheritance of parental DNA methylomes in mammals. Cell 157 979-991. (https://doi.org/10.1016/j. cell.2014.04.017)

Weber M, Davies JJ, Wittig D, Oakeley EJ, Haase M, Lam WL \& Schubeler D 2005 Chromosome-wide and promoter-specific analyses identify sites of differential DNA methylation in normal and transformed human cells. Nature Genetics 37 853-862. (https://doi.org/10.1038/ng1598)

Weksberg R, Shuman C \& Beckwith JB 2010 Beckwith-Wiedemann syndrome. European Journal of Human Genetics 18 8-14. (https://doi. org/10.1038/ejhg.2009.106)

Wernig M, Meissner A, Foreman R, Brambrink T, Ku M, Hochedlinger K, Bernstein BE \& Jaenisch R 2007 In-vitro reprogramming of fibroblasts into a pluripotent ES-cell-like state. Nature 448 318-324. (https://doi. org/10.1038/nature05944)

Woodfine K, Huddleston JE \& Murrell A 2011 Quantitative analysis of DNA methylation at all human imprinted regions reveals preservation of epigenetic stability in adult somatic tissue. Epigenetics and Chromatin $\mathbf{4}$ 1. (https://doi.org/10.1186/1756-8935-4-1)

Xu Y, Goodyer CG, Deal C \& Polychronakos C 1993 Functional polymorphism in the parental imprinting of the human IGF2R gene. Biochemical and Biophysical Research Communications 197 747-754. (https://doi.org/10.1006/bbrc.1993.2542)

Yoder JA, Walsh CP \& Bestor TH 1997 Cytosine methylation and the ecology of intragenomic parasites. Trends in Genetics 13 335-340. (https://doi.org/10.1016/S0168-9525(97)01181-5)

Younis S, Schonke M, Massart J, Hjorteberg R, Sundstrom E, Gustafson U, Bjornholm M, Krook A, Frystyk J, Zierath JR et al. 2018 The ZBED6-IGF2 axis has a major axis has a major effect on growth of skeletal muscle and internal organs in placental mammals. PNAS 115 2048-2057. (https:// doi.org/10.1073/pnas.1719278115)

Yu M, Hon GC, Szulwach KE, Song CX, Zhang L, Kim A, Li X, Dai Q, Shen Y, Park B et al. 2012 Base-resolution analysis of 5-hydroxymethylcytosine in the mammalian genome. Cell 149 1368-1380. (https://doi. org/10.1016/j.cell.2012.04.027)

Yu M, Han D, Hon GC \& He C 2018 Tet-assisted bisulfite sequencing (TAB-seq). Methods in Molecular Biology 1708 645-663. (https://doi. org/10.1007/978-1-4939-7481-8_33)

Zhang S, Kubota C, Yang L, Zhang Y, Page R, $\mathrm{O}^{\prime}$ Neill M, Yang X \& Tian XC 2004 Genomic imprinting of H19 in naturally reproduced and cloned cattle. Biology of Reproduction 71 1540-1544. (https://doi.org/10.1095/ biolreprod.104.031807)

Zhang T, Termanis A, Ozkan B, Bao XX, Culley J, de Lima Alves F, Rappsilber J, Ramsahoye B \& Stancheva I 2016 G9a/GLP complex maintains imprinted DNA methylation in embryonic stem cells. Cell Reports 15 77-85. (https://doi.org/10.1016/j.celrep.2016.03.007)

Received 26January2018

First decision 5March2018

Revised manuscript received 5April2018

Accepted 8May2018 